International Research Journal of Management, IT \& Social Sciences
Available online at https://ijcujournals.us/journals/index.php/irjmis
Vol. 6 No. 1, January 2019, pages: $1-7$
ISSN: 2395-7492
https://doi.org/10.21744/irjmis.v6n1.429

\title{
College Students Utility towards Airtel Services in Theni DT with Special Reference NS College
}

R. Sharumathi ${ }^{\text {a }}$

S. Chitra ${ }^{b}$

\section{Article history:}

Received: 18 July 2018

Accepted: 30 November 2018

Published: 2 December 2018

\section{Keywords:}

airtel services;

college students;

college;

theni;

utility;

\begin{abstract}
In the few decade mobiles was only used for the purpose of and outgoing calls. Now the user is changed because the technology is changing day to day. The value-added services like short message services. Multimedia services $2 \mathrm{G}$ and $3 \mathrm{G}$ and $4 \mathrm{G}$ services were provided by the Airtel service provider. To know the value added services and the customer preferences and satisfaction towards the Airtel services the study has undertaken. To study the origin and growth of Airtel services in Madurai city. To identify the factors influencing the students' utility towards Airtel services in Madurai city. Free text messaging services, free voice mail services, teleconferencing $4 \mathrm{G}$ facilities are provided by Airtel to its students better than competing service providers. This has resulted in switching over of students to Airtel services from other service providers.
\end{abstract}

2395-7492@ Copyright 2019. The Author. Published by SLOAP. This is an open-access article under the CC-BY-SA license (https://creativecommons.org/licenses/by/4.0/) All rights reserved.

\author{
Author correspondence: \\ R. Sharumathi, \\ Nadar Sarawathi College of Arts and Science, Theni, India \\ Email address: raja1996sharu@gmail.com
}

\section{Introduction}

In the few decades Brandon \& Baker (1991), Rinartha et al., (2017), mobile was only used for the purpose of and outgoing calls. Now the user is changed because Sobell et al., (1986), the technology is changing day to day. The value-added services like short message services. Multimedia services $2 \mathrm{G}$ and $3 \mathrm{G}$ and $4 \mathrm{G}$ services were provided by the Airtel service provider. To know the value added services and the customer preferences and satisfaction towards the Airtel services the study has undertaken.

On $24^{\text {th }}$ January 2017, Airtel launched 4G in Maharashtra and goa with 4G network sharing agreement between ideas. Airtel plans to cover 1500 cities across 13 circles by the end of the company which has $4 \mathrm{G}$ licenses for 13 circles, is also in talks with other service providers to roll out the services in the remaining 10 circles as part of its roaming offerings, Airtel had about 3 million 4G subscribers as of May 2017.

\footnotetext{
a Nadar Sarawathi College of Arts and Science, Theni, India

${ }^{\mathrm{b}}$ Nadar Sarawathi College of Arts and Science, Theni, India
} 
Bharti Airtel is the first Indian telecom service provider to achieve this Cisco Gold certification. To earn Gold Certification. Bharti Airtel had to meet rigorous standards for networking competency, service, support and customer satisfaction set forth by Cisco. The company has a submarine cable landing station at Chennai. Which connects the submarine cable connecting Chennai and Singapore Airtel is the $3^{\text {rd }}$ largest in-country mobile operator by subscriber base. Behinds china mobile and China Unicom. It also offers fixed line services and broadband services. It offers its telecom services under the Airtel brand and is headed by Sunil Bharti Mittal

\section{Statement of the Problem}

Ellison et al., (2007), Borsari et al., (2001), the Indian industry has witnessed rapid growth over the last couple of decades. There are many mobile phone services are available but the researcher is going to make an attempt on. Airtel services. The demand of the customer is related to the increase in sometimes and vice versa. Pintrich (2004), Bong (2001), students demand is to be considered as the King of the market. A marketer should fulfill the customer needs. Mahoney et al., (1995), Barrera et al., (1981), stated various 2G and 3G. Brooks \& Betz (1990), Suryasa et al., (2018), is the $4 \mathrm{G}$ services given by the Airtel Company. But it is known to the customers and customers are not aware of the new services provided by the Airtel Company.

\section{Review of Literature}

Nandini has examined the consumer`s utility towards Airtel services in the Madurai city (May`09) emphasized that the major of the consumer preferred to use booster card. Ragini has examined a study on "A study on consumers attitude towards the billing tariff and service provider for mobile phone users by Airtel in Madurai city" in the year 2012 the researcher concluded that the level of the attitude of the consumer of airtel mobile users in satisfactory though not extreme satisfactory. Shylaja has examined a study on "A study on customer satisfaction towards airtel in Madurai city" in the year 2014. The researcher concluded that the customers of Airtel subscriber are expecting many schemes under the net broadband service which they are provided.

\section{Objectives}

1) To study the origin and growth of Airtel services in Madurai city.

2) To identify the factors influencing the students' utility towards Airtel services in Madurai city.

3) To find the purpose of using Airtel services among students.

4) To study the problem and prospects of the Airtel services in Madurai city.

5) To offer suggestions to the policymaker.

The scope of the Study

This study aims to analyze the market area and student's preference and satisfaction towards Airtel services. The enterprise services provide end-to-end telecom solutions to corporate customers and national and international long distance services to carriers. All these services are provided under the Airtel brand. Moreover, the main challenges are to retain the present student's base and try to increase it by providing them better services at affordable price.

\section{Limitations of the Study}

1) The respondents from whom primary data was gathered any times displayed complete ignorance about the complete branded range, which was being studied.

2) Lack of time is the basic limitations of the project.

3) Some of the respondents refused to cooperate with the queries.

4) Some of the respondents gave based or incomplete information regarding the study.

5) Some of the respondents did not answer all the questions or did not have time to answer.

6) Distribution strategies of Airtel are not up to the mark. 


\section{Materials and Methods}

Tools for Analysis

To make the raw data fit for the analysis, the researcher has scrutinized the filled in interview schedule and prepared a master table.it has been designed in such a way as to contain some of the information collected through interview schedule. With the help of the master table, the researcher designed a number of functional tables and analysis was made based on it. The tools used for the analysis are tabulated below.

Statistical Technique Used

The data collected from the respondents are analyzed using various statistical techniques they are as follows:

Percentage Analysis

Percentage method refers to a specified kind which is used in making a comparison between two or more series of data. Percentages are based on descriptive relationship. It compares the relative items. Since the percentage reduces everything to a common base and thereby allow meaning comparison.

Table 1

Age wise classification of respondents

\begin{tabular}{lll}
\hline Age & No of the respondents & Percentage \\
\hline $18-19$ & 16 & $16 \%$ \\
$20-21$ & 47 & $47 \%$ \\
Above-21 & 37 & $37 \%$ \\
Total & 100 & $100 \%$ \\
\hline
\end{tabular}

Source: primary data

Table 1 shows that 16percent of the respondents are in the group below 18-19 years, 47percent of the respondents are in the age group of 20-21 years, 37percent of the respondents are in the age in the age group of above 21 years,

Table 2

Gender wise classification of respondents

\begin{tabular}{lcl}
\hline Gender & No of the respondents & Percentage \\
\hline Male & 55 & $55 \%$ \\
Female & 45 & $45 \%$ \\
Total & 100 & $100 \%$ \\
\hline
\end{tabular}

Source: primary data

Table 2 shows that out of 100 respondents, 55 percent of the respondents were male and 45 percent respondents were female.

Table 3

Know About Airtel Services

\begin{tabular}{lll}
\hline Know about Airtel services & No of the respondents & Percentage \\
\hline Friends & 31 & $31 \%$ \\
Advertisement & 48 & $48 \%$ \\
Family & 20 & $20 \%$ \\
Others & 1 & $1 \%$ \\
Total & 100 & $100 \%$ \\
\hline
\end{tabular}

Source: primary data

Sharumathi, R., \& Chitra, S. (2018). College students utility towards airtel services in theni DT with special reference NS college. International Research Journal of Management, IT and Social Sciences, 6(1), 1-7. https://doi.org/10.21744/irjmis.v6n1.429 
Table 3 shows that most of the 31 percent in friends, and 48 percent in the advertisement, and 20 percent in family member's and1percent in others Airtel services.

Table 4

Classification On Basis Type Of Airtel Services

\begin{tabular}{lll}
\hline type of Airtel services & No of the respondents & Percentage \\
\hline Prepaid & 98 & 98.0 \\
Postpaid & 2 & 2.0 \\
Total & 100 & 100.0 \\
\hline
\end{tabular}

Source: primary data

Table 4 shows that 98 percent of the respondents are using prepaid services and 2 percent of respondents are using post-paid services.

\section{Results and Discussions}

a) It was found that out of 100 respondents majority of the respondents 16 percent are in the age group 18-19 years, secondly 47 percent of the respondents in 20-21 years age next finally 37 percent of the respondents in Above 21 years.

b) It was found that out of 100 respondent's majority of the respondents 55 percent Male and female 45 percent.

c) It was found that out of 100 respondent's majority of the respondents 9 percent of the married and 91 percent of the respondents unmarried.

d) It was found that out of 100 respondents 14 percent of the respondents belong to the income group of less than 10,000 and 30 percent of the respondents belong to the income group of 10,000-15,000 and 32percent of the respondents belong to the income group 15,000-20,000 and 24percent of the respondents belong to the income group of Above 20,000.

e) Regarding the education level of respondents most of the undergraduates, 36per cent of postgraduates 64per cent of the respondents.

f) Regarding the know about 100 respondents most of 31 per cent of the respondents of the friends and 48 per cent of the respondent's advertisement and $20 \%$ family members in 1per cent in the respondents in others.

\section{Conclusion}

Free text messaging services, free voicemail services, teleconferencing $4 \mathrm{G}$ facilities are provided by Airtel to its students better than competing service providers. This has resulted in switching over of students to Airtel services from other service providers. This has contributed to an increased market share of Airtel services and hence, Airtel shows an upward trend.

\section{Suggestions}

Respondents are not fully aware of Airtel utility schemes. Hence, adequate promotional measures are to be taken for promoting such schemes. To prevent misuse of the service identifications of the respondents should be verified. Better value-added services can be provided for students. Students can be provided with proper training for better Airtel services.

Conflict of interest statement and funding sources

The authors declared that they have no competing interest. The study was financed by personal funding.

Statement of authorship

The authors have a responsibility for the conception and design of the study. The authors have approved the final article. 
Acknowledgments

The authors would like to thank the reviewer for their consideration the further process of the present paper. Thanks to the editor of IRJMIS for their valuable support, time as well as advice.

Sharumathi, R., \& Chitra, S. (2018). College students utility towards airtel services in theni DT with special reference NS college. International Research Journal of Management, IT and Social Sciences, 6(1), 1-7. https://doi.org/10.21744/irjmis.v6n1.429 


\section{References}

Barrera, M., Sandler, I. N., \& Ramsay, T. B. (1981). Preliminary development of a scale of social support: Studies on college students. American Journal of Community Psychology, 9(4), 435-447. https://doi.org/10.1007/BF00918174

Bong, M. (2001). Role of self-efficacy and task-value in predicting college students' course performance and future enrollment intentions. Contemporary educational psychology, 26(4), 553-570. https://doi.org/10.1006/ceps.2000.1048

Borsari, B., Neal, D. J., Collins, S. E., \& Carey, K. B. (2001). Differential utility of three indexes of risky drinking for predicting alcohol problems in college students. Psychology of Addictive Behaviors, 15(4), 321.

Brandon, T. H., \& Baker, T. B. (1991). The Smoking Consequences Questionnaire: The subjective expected utility of smoking in college students. Psychological Assessment: A Journal of Consulting and Clinical Psychology, 3(3), 484.

Brooks, L., \& Betz, N. E. (1990). Utility of expectancy theory in predicting occupational choices in college students. Journal of Counseling Psychology, 37(1), 57.

Ellison, N. B., Steinfield, C., \& Lampe, C. (2007). The benefits of Facebook "friends:" Social capital and college students' use of online social network sites. Journal of Computer-Mediated Communication, 12(4), 1143-1168. https://doi.org/10.1111/j.1083-6101.2007.00367.x

Mahoney, C. A., Thombs, D. L., \& Ford, O. J. (1995). Health belief and self-efficacy models: Their utility in explaining college student condom use. AIDS education and prevention.

Marsh, H. W. (1984). Students' evaluations of university teaching: Dimensionality, reliability, validity, potential baises, and utility. Journal of educational psychology, 76(5), 707. http://psycnet.apa.org/doi/10.1037/00220663.76.5.707

Pintrich, P. R. (2004). A conceptual framework for assessing motivation and self-regulated learning in college students. Educational psychology review, 16(4), 385-407. https://doi.org/10.1007/s10648-004-0006-X

Rinartha, K., \& Suryasa, W. (2017, August). Comparative study for better result on query suggestion of article searching with MySQL pattern matching and Jaccard similarity. In Cyber and IT Service Management (CITSM), 2017 5th International Conference on (pp. 1-4). IEEE. https://doi.org/10.1109/CITSM.2017.8089237

Sobell, M. B., Sobell, L. C., Klajner, F., Pavan, D., \& Basian, E. (1986). The reliability of a timeline method for assessing normal drinker college students' recent drinking history: Utility for alcohol research. Addictive behaviors, 11(2), 149-161. https://doi.org/10.1016/0306-4603(86)90040-7

Suryasa, I. W., Prayoga, I. G. P. A., \& Werdistira, I. W. A. (2018). Attitudes toward the use of internet for students. International Journal of Physical Sciences and Engineering, 2(2), 32-38. https://doi.org/10.29332/ijpse.v2n2.141 


\section{Biography of Author}

\begin{tabular}{||l|l||}
\hline & $\begin{array}{l}\text { R. Sharumathi., M.Phil, Commerce, is a lecturer and researcher in the Nadar Sarawathi } \\
\text { College of Arts and Science, Theni, India. Pincode: 624202, Ph. +9842139817 \& } \\
+9003614162 \\
\text { Email: raja1996sharu@gmail.com }\end{array}$ \\
\hline
\end{tabular}

Sharumathi, R., \& Chitra, S. (2018). College students utility towards airtel services in theni DT with special reference NS college. International Research Journal of Management, IT and Social Sciences, 6(1), 1-7. https://doi.org/10.21744/irjmis.v6n1.429 